DOI: $10.24193 /$ tras.61E.7

Published First Online: 10/28/2020

\title{
DEMAND ELASTICITY FOR \\ LOCAL PUBLIC TRANSPORT \\ IN POLISH CITIES: \\ DO LOCAL POLICIES MATTER?
}

\section{Paweł SWIANIEWICZ Agata BRZÓSKA}

\section{Paweł SWIANIEWICZ (corresponding author)}

Professor, Department of Local Development and Policy, University of Warsaw, Warsaw, Poland

Tel.: 0048-22-552.0650

\section{Abstract}

Since 1990, the number of local public transport passengers has been steadily decreasing with a simultaneous increase in the number of residents using individual transport. Since that process has contributed to an increase in traffic congestion and the deterioration of air quality in cities, local governments have tried to reverse that negative trend. A few years now, a reversal of this trend has been observed in some cities.

This article, using data on the number of passengers in over 80 Polish cities, presents regression models explaining the factors influencing the demand for public transport services, and it estimates the demand elasticity related to various independent variables. The explanatory model refers both to the features of the cities' socio-economic environment and to the organization of the service.

The results indicate that local policies matter: the density of the public transport network is the most important factor in relation to the volume of demand, while the ticket price level is almost irrelevant. Demand is also clearly increasing in the largest cities, but the relationship between demand and population size is not a linear one.

Keywords: local public transport, demand elasticity, price elasticity, local government, Poland.

\section{E-mail: p.k.swianiewicz@uw.edu.pl}

\section{Agata BRZÓSKA}

Department of Local Development and Policy, University of Warsaw, Poland

Research Assistant, Institute of Rural and Agricultural Development, Polish Academy of Sciences, Warsaw, Poland E-mail: abrzoska@irwirpan.waw.pl 


\section{Introduction}

The development of individual motorization combined with cultural changes has led to a decrease in the level of public transport services in cities in different countries, including Poland. According to Dargay and Hanly (2002), the average decrease in the number of passengers carried by public transport in British municipalities was $20 \%$ in 1986-1996. This phenomenon had numerous negative side effects. Excessive concentration of private transport resulted in traffic jams, inconvenience due to scarcity of parking spaces, reduced attractiveness of cities for pedestrians, excessive noise and increased air pollution, which was dangerous not only in terms of immediate consequences for residents but also in terms of the negative impact on global climate change.

There is therefore a need to develop urban policies that increase the attractiveness of urban public transport. The question arises as to why it has been possible to stop the trend of the decrease in the number of passengers in some cities, while in others the negative trend continues. Is it determined by the policies implemented by local authorities and, if so, which of them are likely to be the most effective? Or is the social context related to the characteristics of individual cities predominant? We try to answer these questions in this article, which goal is to find factors that determine the elasticity of demand for urban public transport services.

The article consists of five parts, beside the current introduction. In the second section, we discuss the theoretical framework based on the results of previous research. In the third one we formulate hypotheses, while the fourth section focuses on the presentation of data sources and empirical strategy. The fifth part presents mostly in a descriptive manner - general changes in the use of local public transport in Polish cities in recent years and the sixth part includes hypothesis testing. Finally, the seventh section is a discussion of the results of the empirical tests conducted and conclusions.

\section{The factors affecting demand for local public transport in the light of past research}

Given the high and growing political relevance of the topic in recent years, empirical studies of demand determinants in urban public transport are surprisingly scarce. This statement definitely applies to Poland, where the existing studies are either a discussion of research conducted in other countries or model considerations based on theoretical concepts, but poorly supported by methodologically solid data analysis (Bąkowski, 2014; Dydkowski et al., 2018). However, available empirical tests are not very numerous in the international academic literature either. Holmgren (2007) points out that until the end of the 20th century, price elasticity studies dominated, while relatively recently there have been more studies analyzing other factors of elasticity of demand for local public transport.

One of the most frequently asked questions is that of the effectiveness of different types of urban policies. The focus is, therefore, on estimating the demand function by determining its elasticity in relation to various explanatory variables. 
The level of demand may be affected by two types of variables (Brechan, 2017). The first refers to the organization of transport itself and can, therefore, be shaped to some extent by urban policy. The two most important factors highlighted in previous studies are the quality of service and price. The former is measured in a variety of ways. In a study of the Madrid region, Matas (2004) uses the variable of the length of all courses. Its high value may indicate both a satisfactory coverage of the area by a transport network (network density) and a high frequency of travel by means of transport, which is one of the main demands made by passengers in relation to urban transport (Hebel, 2014). In his study, Matas also tests average speed, average frequency and the number of kilometers travelled. The latter variable is also used by Dargay and Hanly (2002), Romilly (2001) and Bresson et al. (2003), referring it to the population of the city examined. In turn, Daldoul et al. (2016) and Deb and Filippini (2013) define the quality of service as the density of the communication network.

Romilly (2001), on the other hand, also uses a variable concerning the age structure of rolling stock (bus fleet). According to available tests, the quality of communications - though measured differently - is positively correlated with demand. Often (e.g. Matas, 2004) it is the most powerful independent variable. Some studies show that quality (in this case measured by the frequency of travel) has a stronger impact on passenger numbers than a reduction in ticket prices (Brechan, 2017). Holmgren (2007) also concludes that the availability of a service (measured in terms of vehicle-kilometers) has the greatest impact on demand - higher than price and other variables he considers in his study. However, Holmgren (2013) notices a methodological problem related to the study of the impact of the quality of services measured by the frequency of operation as his variable, as well as some others included in various studies, is not fully exogenic; for example, the frequency of operation of city buses depends also on past demand, so it cannot be treated exclusively as a variable related to urban policies. As Holmgren (2013) states: 'there are good reasons to believe that although quality of service certainly affects demand, the level of demand also affects the level of service (...). Despite this, the most common practice in statistical/econometric applications is to assume that quality causes demand and not the other way around' (p. 102).

Our model is based on a similar assumption; however, the direction of the causal relationship may influence the policy implications stemming from the study to a very limited extent only.

Several studies indicate the elasticity of demand in terms of price: the higher the ticket price, the fewer passengers are carried. According to Dydkowski et al. (2018) price elasticity of demand in urban transport in Poland is low $(-0.38)$ and is associated with a low level of fares. But Holmgren (2007) identifies even higher price elasticity (although lower than the elasticity with respect to service quality), additionally pointing to differences between different parts of the world. Above a certain threshold the price elasticity of demand is increasing (Dargay and Hanly, 2002). Alternative costs (time value, cost of nuisance) should also be considered in order to take full account 
of the demand response to the factor in question. In empirical studies, they are expressed as costs associated with owning and using a car. Matas (2004) and Holmgren (2017) use the petrol price index here, while Dargay and Hanly (2002) as well as Romilly (2001) use more general automotive costs that reflect both car purchase and day-to-day maintenance costs. Increasing these costs may be one of the ways of influencing the demand for public transport (Bąkowski, 2014). The instruments available to city authorities in this respect include, for example, the policy on the number and cost of parking spaces as well as charges for entering the city center.

The second group of factors is related to the environment in which the urban transport company operates, i.e. the economic situation of the city and the socio-demographic status of residents. Holmgren (2007), in his meta-analysis of earlier studies, considers the income of residents, the price of fuel (affecting the cost of alternative transport) and the number of private cars. In a study of the Madrid region, Matas (2004) indicates that the growing level of suburbanization (expressed in the suburban population in relation to the total population of the region) has a positive impact on the demand for urban transport services. Some studies also point to the economic activity of the society in question, especially commuting to work (Matas, 2004; Deb and Filippini, 2013; Daldoul et al., 2016). As regards the characteristics of the demographic and social structure, Dargay and Hanly (2002) study the impact of the increase in the number of pensioners: they assume that seniors, due to a greater amount of free time, use public transport services more often. Daldoul et al. (2016), in a study of Tunisian public transport, test the impact of feminization. Recalling the results of previous studies (De Palma and Lindsey, 2001), they suggest that time is of greater value to men, which can be justified by the statistically higher salaries of men (so the cost of the per hour labor force is higher). They assume, therefore, that the demand for public transport should increase with a higher number of women in the population (public transport is more time consuming), but their empirical test did not confirm this relationship.

The wealth of the population is a very good example that demonstrates how the direction of dependency can vary in different local (cultural) contexts. Higher incomes may limit the demand for public transport, but the relationship may also be positive: the increased wealth of the population may result in more users of public transport services. In a study on India, Deb and Filippini (2013) consider the literacy rate, which is positively correlated with the wealth of the population. They refer to Dargay and Hanly's (2002) thesis that describes public transport as an inferior good, for which demand decreases along with an improvement in the material condition of the population. However, a situation in which the increase in income is accompanied by an increase in demand for passenger transport services may occur in large cities, where the quality of urban transport is high. At that time, it is treated as a substitute for a car, the possession of which is not significantly sensitive to changes in the financial situation of the population (Asensio et al., 2003 apud Matas 2004). This phenomenon intensifies particularly in cities with a high population density, where public 
transport seems to be a more attractive solution due to numerous side effects related to congestion or a shortage of parking spaces. Bąkowski (2014) notes that even within a single city, a two-way impact of the affluence of residents on demand can be distinguished, depending on whether they belong to a specific socio-economic group.

Our study refers to this earlier research but it provides new elements in at least two respects. First, in terms of geographical coverage. There have been no similar studies published so far in international journals, not only concerning Poland but also the wider region of Central and Eastern Europe. And - as has been demonstrated by earlier studies - factors influencing demand for city public transport are sensitive to the context of local culture and economic development. All countries of the region have experienced a rapid increase of private car ownership in the early stages of the economic and political transition of the 1990s at the same time as the painful transformation of inefficient publicly owned companies, including those responsible for urban public transport. Both of these factors have had a direct impact on changes in the demand and supply of transport services. Therefore, checking these factors in a Polish context provides interesting, new knowledge. Second, the most comprehensive meta-analysis providing information on demand elasticity of public transport in cities, performed by Holmgren (2007), is based on empirical research published at the turn of the 20th and 21st centuries. There are not many studies that rely on data from recent years, while the changes in recent years have been very dynamic. The dominant trends in thinking on urban planning, the importance of climate change and environmental consciousness have changed a lot during the last two decades, and all of them are of crucial importance for transport policies and for the demand for public transport services. So, conducting a study based on the most recent data may provide a new insight into the studied topic.

\section{Research questions and hypotheses}

The factors discussed above will be used for the empirical test in our article. We are interested in estimating how the selected factors influence local public transport demand in Polish cities. Our research focuses on the period 2014 - 2017. The collected data allowed us to analyze the trend of changes in a relatively short period of time. In order to verify to what extent the analysis of such a short period may be generalized, in section 4 (see figures 2 and 3) we try to confirm the observed trends based on data for a smaller group of cities but covering a longer period.

The first hypothesis concerns the socio-economic environment in which the transport functions, while the second is directly related to the organization of urban transport.

Hypothesis 1: The demand for urban transport services is positively influenced by the following socio-economic features of cities:

- 1.1. City size;

- 1.2. Population density;

- 1.3. Wealth of urban budget; 
- 1.4. Affluence of local population (in this case we may expect the relationship to be both positive and negative); and

- 1.5. Unemployment rate (in this case - negative correlation is expected).

The impact of city size on demand for public transport can be considered in relation to economy of scale, which determines the relationship between the size of a local government unit and the present value of benefits. Due to the lower marginal cost, we can expect that in larger cities it will be possible to establish a lower service charge, which in turn will be an attractive solution for residents. In addition, in large centers, encouraging public transport is a way to reduce the negative externalities generated by car traffic. Another argument pointing to the positive impact of Polish city size on demand refers to the issue of education of residents. The level of education - according to data from the National Census 2011 - positively correlates with the size of the city. The largest proportion of inhabitants with higher education $(30.1 \%)$ is in cities of more than 250,000 inhabitants, while in cities between 150,000 and 250,000 it drops to $21.8 \%$; it is measured at $19.7 \%$ in other regional and sub-regional centers, and at $12.7 \%$ in rural districts. This may be influenced by the fact that the inhabitants of the largest cities, who are concerned about the environment as a result of their deeper ecological awareness, more often (than the inhabitants of smaller cities) choose to travel by public transport.

An important factor may also be the high population density, which is conducive to keeping the costs of urban transport at a lower level. At the same time, the higher the population density in the city the greater the intensity of traffic, which translates into traffic jams. On the other hand, low density indicates the existence of dispersed development and longer distances connecting particular points in the municipality, which translates into higher marginal costs of service provision.

We also expect that the demand may be positively influenced by the affluence of municipal budgets. This service usually requires significant subsidies from the municipal budget. In recent years, a systematic increase in local government subsidies for this purpose has been observed in Poland (Dydkowski et al., 2018). Local governments that do not want to significantly increase ticket prices have to consider the higher budget burden that communications will generate. Such a policy can be pursued by large cities, which, while maintaining a certain level of service without changing tariffs, are able to maintain a high network density.

It may be more complicated to take the level of wealth of the inhabitants into account. The affluence of the population can have a two-way effect on demand. First, it may increase the number of passengers. This may be the case in cities where urban transport, due to its high quality, is a substitute for the car. As already mentioned above, this effect intensifies in cities with a high population density (Matas, 2004). Greater wealth can also increase demand through greater environmental awareness and the trend towards eco-friendly living. On the other hand, as many previous studies have shown, the healthy material situation of the population may also contribute to a decrease in demand due to the perception of urban transport as an inferior good 
(Dargay and Hanly, 2002). The material situation of particular social groups may, therefore, determine different transport behavior. Also, Holmgren (2007), in his review of earlier studies, points to a very significant difference in the results in this respect - in various studies, the elasticity of demand in relation to the income of residents is different.

The last factor examined in the first hypothesis refers directly to the professional activity of the society in question, as we assume that working residents positively influence the demand for urban transport services due to their regular use of commuting services. This factor turned out to be important in previous empirical studies (Dargay and Hanly, 2002; Daldoul et al., 2016).

Hypothesis 2: The demand for urban transport services is positively influenced by the organizational characteristics of public transport:

- 2.1. Ticket prices; and

- 2.2. Quality of urban transport services.

The first part of the second hypothesis refers to the economic assumption of the price elasticity of demand. As the price of goods increases, demand decreases. This is not necessarily related to the price of rides only. Discounts or exemptions for certain social groups or, in extreme cases, the establishment of free public transport for all may also be important for stimulating demand.

The second part of the hypothesis refers to the quality of transport services, which often consists of elements such as journey duration, comfort and safety (Hebel and Horon, 2002), as well as network density, which is one of the most important and frequently reported demands for urban transport. According to some earlier studies (e.g. Matas, 2004; Holmgren, 2007), the quality factor is the strongest determinant of demand. In our study we measure quality by the network density as well as by the availability of alternative (to the bus) means of public transport (e.g. tram, underground, which play a role in avoiding traffic jams). Initially, we planned also to take the mean age of the rolling stock into account (newer buses usually provide more comfortable travel conditions), but eventually this variable was omitted due to problems with data availability (a relatively high number of missing values in our sample). However, our partial analysis of that variable has shown a low correlation with the dependent variable.

\section{Scope and method of empirical testing}

The research covers a sample of 86 Polish cities that organize public transport. According to Menes (2016) there are 260 Polish cities that organize local public transport. Therefore, our sample is one third of the total population. However, our coverage of the largest cities is much higher - our sample includes $64 \%$ of all cities with a population of over $100,000,53 \%$ of cities with a population of between 50,000 and 100,000, $24 \%$ of cities with a population of between 30,000 and 50,000 and only $13 \%$ of smaller towns that organize their public transport systems. Due to problems with comparabil- 
ity, we have omitted the cities in which local public transport is organized by municipal associations. The basic source of data were bulletins published by the Chamber of Commerce of Urban Transport (Izba Gospodarcza Komunikacji Miejskiej), in some cases supplemented by data obtained directly from municipal companies or city councils. The remaining data used comes from the Main Statistical Office of Poland.

Demand for local public transport is expressed relatively as the number of passengers in relation to the number of inhabitants. This method of measuring demand refers to measures used in previous studies. The number of passengers (in relation to the population) was used, among others, by Dargay and Hanly (2002) and the number of journeys by Matas (2004) as well as by Romilly (2001). Such operationalization has limitations, e.g. it omits the length of each trip (Deb and Filippini, 2013) or generates errors in the correct estimation of the exact value resulting from measurement difficulties. However, these imperfections have been considered acceptable in most earlier studies, as they have not produced bias in the final results.

Tables 1 and 2 show the operationalization of the factors influencing the demand for urban transport services.

Table 1: Operationalization of factors influencing demand in the 2014-2017 period

- factors related to socio-economic environment

\begin{tabular}{ll}
\hline \multicolumn{1}{c}{ Factors } & \multicolumn{1}{c}{$\begin{array}{c}\text { Independent variables } \\
\text { influencing demand }\end{array}$} \\
\hline City size (L.1.1.) & Population \\
Population density (L.1.2.) & Population per km² \\
\hline Affluence of city budget (L.1.3.) & Per capita budget own revenues \\
Affluence of local population (L.1.4.) & Per capita personal income tax \\
Unemployment rate (L.1.5.) & Index of unemployment \\
\hline
\end{tabular}

Table 2: Operationalization of factors influencing demand in the 2014-2017 period - factors related to urban transport policies

\begin{tabular}{|c|c|c|}
\hline \multicolumn{2}{|c|}{ Factors } & Independent variables influencing demand \\
\hline \multirow{2}{*}{\multicolumn{2}{|c|}{$\begin{array}{l}\text { Ticket prices } \\
\text { (L.2.1.) }\end{array}$}} & Price of single ride ticket allowing for 30 minutes ride at least \\
\hline & & $\begin{array}{l}\text { Other than resulting from national law exemptions from paying } \\
\text { for tickets introduced for large social groups }{ }^{*} \text { (binary variable } 0.1 \text { ) }\end{array}$ \\
\hline \multirow{2}{*}{$\begin{array}{l}\text { Quality of urban } \\
\text { transport services } \\
\text { (L.2.2.) }\end{array}$} & \multirow{2}{*}{$\begin{array}{l}\text { Density of network and } \\
\text { frequency of operation }\end{array}$} & Number of vehicle-kilometers per capita \\
\hline & & $\begin{array}{l}\text { Existence of other means of city public transport (than buses, } \\
\text { e.g. tram, underground) (binary variable) }\end{array}$ \\
\hline
\end{tabular}

Note: $\star$ E.g. for school students, unemployed or - in extreme cases - public transport free of charge for all citizens.

The method of testing our hypothesis is panel data analysis, based on the Fixed Effects model (FE) ${ }^{1}$. The selection of FE model was based on results of the Hausman

1 As a robustness check we also used the Random Effect (RE) and Ordinary Least Squares (OLS) models. Their results confirm the most important conclusions of our test. 
test. Various sets of independent variables (from among those listed in Tables 1 and 2) were tested, out of which we present only those that provided the greatest explanatory power of the model. We are aware of some of the shortcomings of the model. One of them is taking mainly bus travel into account as the means of public transport. In general, in most Polish cities the main means of local public transport is the bus. But there is also a group of cities where the number of trips is an aggregate of bus, tram, underground trips and even bikes. Therefore, vehicle-kilometers are also aggregated over different means of transport. Following Holmgren (2013) we must also consider another potential problem concerning the existing differing preferences between inhabitants of municipalities. But, because we are using the FE model, there is a municipal-specific effect in the model). This makes it possible to include unobserved factors, specific for each municipality, that influence the demand, which correlate with another independent variable. These factors might be related to, for example, demographic structure (this concerns the age structure or number of students), geographical or infrastructural factors.

Due to the fact that the distribution of most of our independent variables deviates significantly from normal, the variables which are used in the model are logarithms of the raw variables (the distribution of variables was analyzed through the Jarkue-Bera test).

As mentioned above, all independent variables enumerated in Tables 1 and 2 have been tested in the constructed equations; however, results presented in this article concentrate on the set of variables that brought the best results in terms of the explanatory power of the model. That final selection includes the following four variables: (V) number of vehicle-kilometers per capita, (I) per capita personal income tax, $(\mathrm{P})$ price and $(\mathrm{D})$ population density; the equation has the form:

$$
\ln q_{i, t}=\beta_{1} \ln V_{i, t}+\beta_{2} \ln I_{i, t}+\beta_{3} \ln P_{i, t}+\beta_{3} D_{i, t}+\varphi_{i}+\varepsilon_{i, t}
$$

Comparing ticket prices is complicated as very diversified tariff systems in individual cities are used. Even the category of 'single ride ticket' is not easy to define because it may depend on how long the trip is, and definitions applied in individual cities vary significantly. In our model we consider the price of tickets that allow for a single ride of at least 30 minutes. The median price for such a ticket in Poland is just 2.7 złoty (less than 0.65 euro) and varies in our sample from 1.6 złoty ( 0.35 euro approx.) to 4.6 złoty (1.05 euro approx.). It is relatively low compared to mean gross monthly income, since it allows users to purchase more than 1,850 tickets per month. In fact, the real cost of using public transport is even lower, since most cities have introduced various forms of monthly or quarterly passes with preferential prices. For example, in Warsaw the full price of a quarterly ticket is equivalent to just 19 single ride tickets per month.

The dominant means of public transport in Poland is the bus; in our sample just 11 out of over 80 cities provides an alternative (usually trams).

Taking the tested variables illustrating the organization of public transport into account, the largest variation can be found in the number of vehicle-kilometers per 
capita. The median value is 27 but, in our sample, it varies from 7 to 144, i.e. the highest value is over 20 times higher than the lowest.

\section{Local public transport in Polish cities - changes in demand}

Polish cities enjoy considerable discretion in organizing their public transport services. Most of the largest cities have created Transport Authorities, which contract transport services either from municipally owned companies or from private sector companies. In other, mostly mid-sized cities the transport services are directly organized and provided by municipal companies or in-house departments. In some cases, transport is organized through inter-municipal cooperation (the largest of such inter-municipal institutions operates in the agglomeration of Upper Silesia) and several smaller suburban municipalities purchase transport services from their larger neighbors. But, regardless of whether the service is purchased from private or delivered by municipally owned units, in each case the local government decides upon tariffs and indirectly controls the route network as well as the frequency of operation.

Demand for public transport services in Poland has drastically decreased over the last 30 years. The decrease in the number of passengers by almost $60 \%$ between 1986 and 2017 is a result of many factors (Figure 1). Menes (2016) mentions several factors, including the economic crisis of the late 1980s and early 1990s, the crisis in urban transport related to the transfer of new tasks to local governments under the Act on Local Government of 1990 without additional support from the central government, socio-demographic changes (e.g. an ageing population), a reduction in the quality of means of public transport with a simultaneous increase in service charges and the dynamic development of individual motorization. As regards this last factor, Dydkowski et al. (2018) note a faster increase in prices of urban public transport in relation to fuel prices (their analysis covers the years 2007-2016). This contributes to a reduction in the attractiveness of public transport compared to the alternative of using a private car; on average more than every second resident in Poland has their own car (Dydkowski et al., 2018). The problem related to the dependence of the population on individual motorization is common throughout Europe and was earliest recorded in Western Europe. In 2014, the share of car journeys in relation to all journeys made was 20 percentage points higher than in Central Europe (Poliak et al., 2017). However, this is more the heritage of the distant past than the result of the processes taking place in recent years, in which the comparison of trends looks to be the other way around. In the years 2000-2014 the increase in the share of private car journeys was higher by more than four percentage points in the group of Central European countries compared to Western Europe. This may mean that the number of motor vehicles in Western Europe has reached saturation level (in some large cities it has even started to decrease), in contrast to Central and Eastern Europe, where it has continued to grow (Poliak et al., 2017).

Analyzing the dynamics of the demand for urban transport services in Poland, we can see that the declining trend has slowed down significantly in recent years. The 


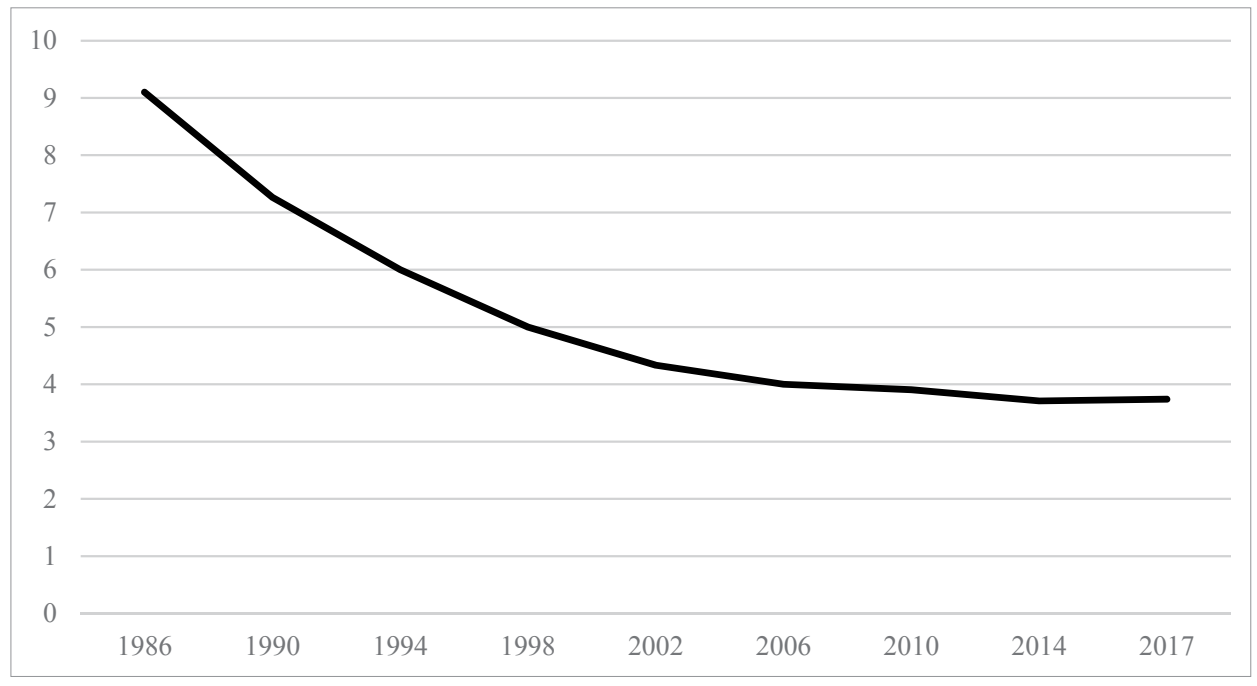

Figure 1: Demand for urban public transport in Poland 1986-2017 - number of passengers (in million)

Source: Own calculations based on Menes (2016) and Main Statistical Office data

number of passengers carried in 2004 decreased by $54 \%$ compared to 1986 . However, over the next 13 years (2004-2017) the decrease amounted to less than $10 \%$. What could have caused this change? On the one hand, it may be the effect of the slow saturation with individual cars as discussed above. On the other hand, it may result from a change in the perception of urban transport services. Some studies indicate that for several years now, there has been an increase in demand for this service in Poland, mainly in the largest urban centers (Wolański et al., 2016).

In the next section of the article, examining the factors that influence the changes in demand for local public transport services, we limit ourselves to the relatively short period of 2014-2017, for which we managed to collect data covering a significant group of cities. The question arises as to what extent the trends of change in this period are representative (typical) compared to a trend that is characterized by a longer period of time. In this case, however, it was possible to collect data covering 2009-2017 period for a much narrower sample of 23 cities, additionally divided - in accordance with the suggestion from the above-mentioned work by Wolański et al. (2016) - into two groups: smaller cities and cities with more than 150,000 inhabitants.

As can be seen in Figure 1, since at least 2009 a stable number of passengers has been observed. But the demand has been slowly growing in this period in large cities (Figure 2), while in smaller cities it has been constantly decreasing (Figure 3). Thanks to this analysis of a longer trend, we can formulate our conclusions based on the empirical study presented in Part 5 with a greater amount of certainty. 


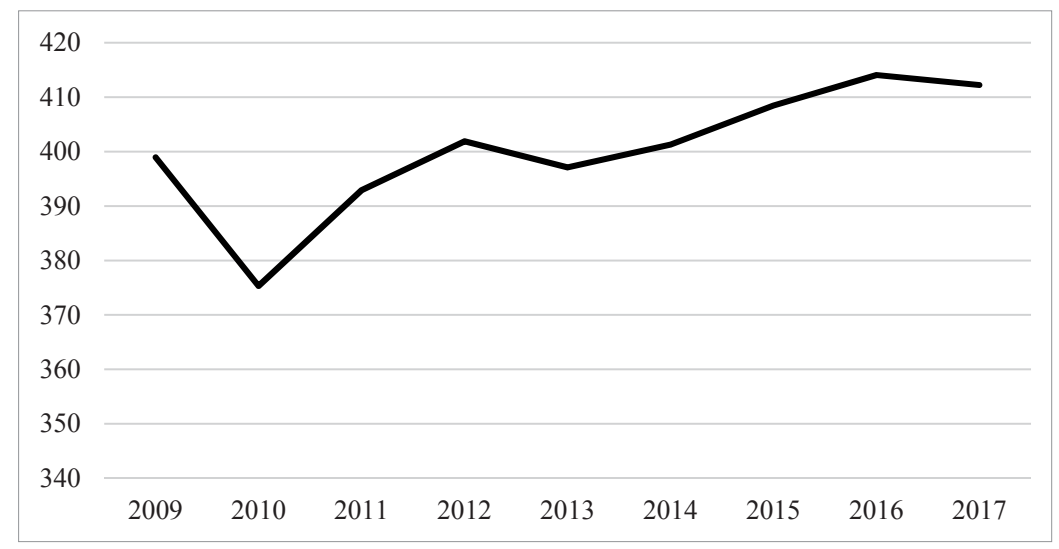

Figure 2: Number of passengers per number of population in 2009-2017 in cities over 150,000

Source: Own calculations, $\mathrm{N}=10$

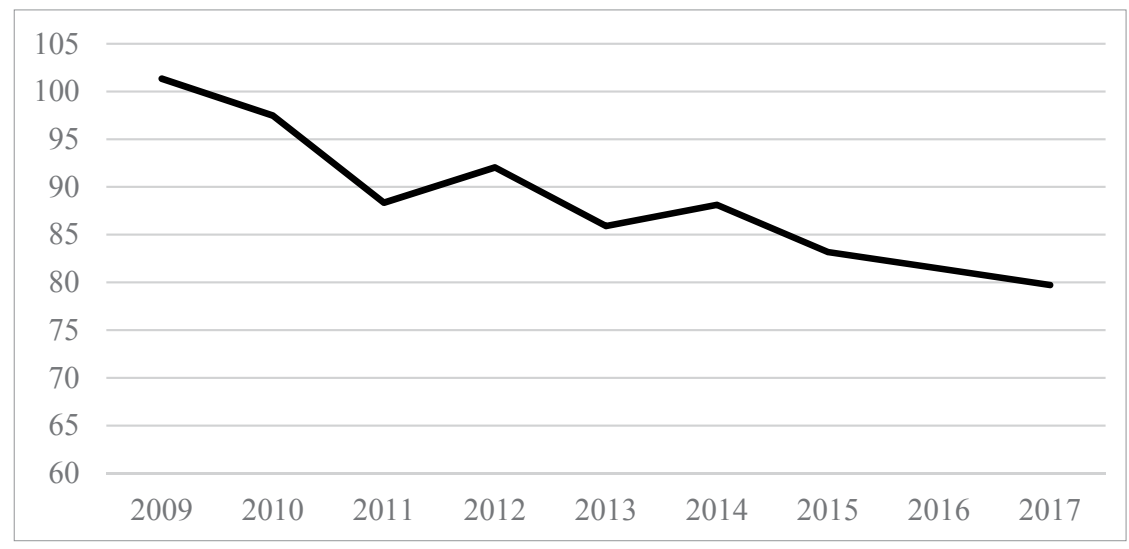

Figure 3: Number of passengers per number of population in 2009-2017 in cities below 150,000

Source: 0 wn calculations, $\mathrm{N}=13$

\section{Results of empirical analyses}

\subsection{City size as a factor explaining the demand for local public transport}

The data presented in the previous section suggest a closer look at the impact of city size on the changes in demand and size for local public transport is necessary. In the sample of cities surveyed the change in 2014-2017 period ranged from a decrease of $19 \%$ to an increase of $18 \%$. In over $60 \%$ of cities there was a drop in demand.

However, in less than $40 \%$ of cities we observed a reverse trend: Figure 4 suggests that the observation of Wolański et al. (2016) about the special situation of the biggest cities is to a large extent correct. However, this dependence is not linear and, therefore, the correlation coefficient between the size of the city and the change in demand for public transport turns out to be at a low level. 


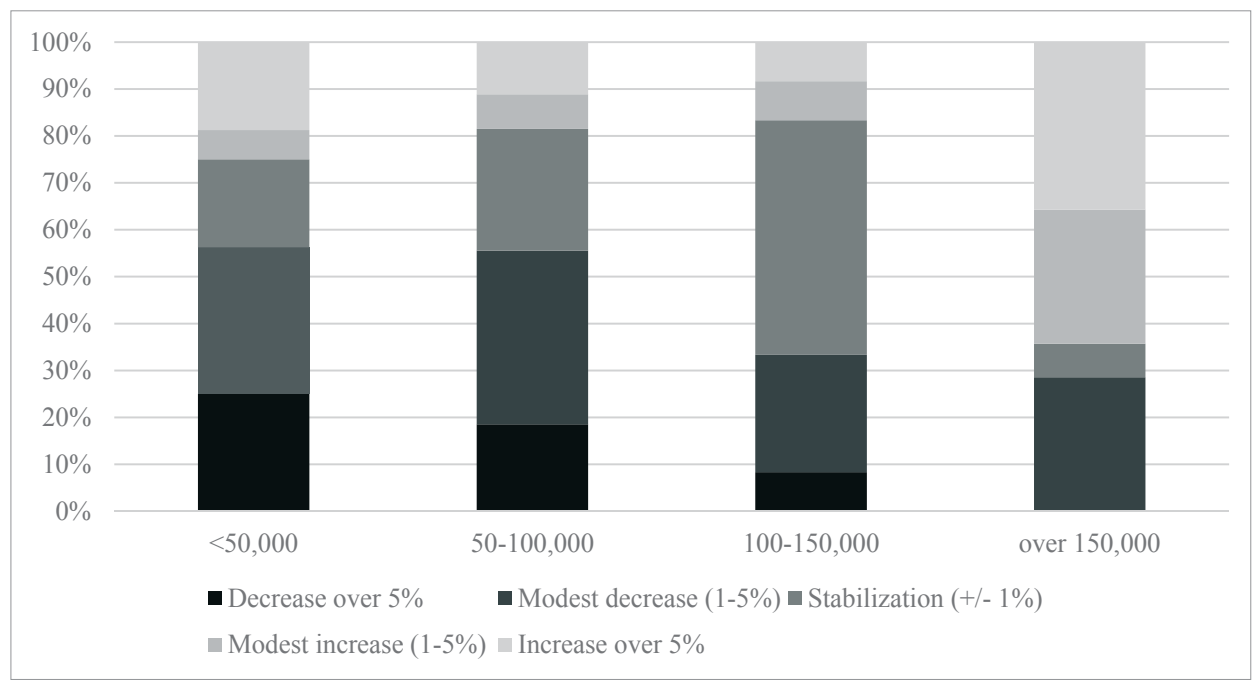

Figure 4: Changes in number of passengers in 2014-2017 period and city size

Source: Own calculations on the basis of data from the Chamber of Urban Public Transport, $N=85$

The 150,000-inhabitant level turns out to be a significant threshold. The change in demand is greater than zero in more than two-thirds of the cities belonging to this group. Meanwhile, in all groups of smaller cities, there are predominant cases where the downward trend in the number of urban transport passengers continues. Additionally, this dependence is confirmed by the results of the $t$-student test for independent samples, which show that in cities above 150,000 inhabitants, the annual change in the relative number of passengers is higher than in smaller cities. The impact of the size ceases to be so clear when we compare individual groups of cities with less than 150,000 inhabitants. While the percentage of cities with a significant decrease in passenger numbers decreases significantly with the population growth, the distribution of cities with a growing demand for local public transport is much less clear.

These observations are only a starting point for further analysis, in which we examine the impact of the various explanatory variables on the volume and changes in demand for local public transport services more systematically.

\subsection{Factors affecting demand for local public transport services - explanatory model}

The constructed regression model shows significant predictive power. The adjusted $\mathrm{R}^{2}$ indicator is as high as 0.68 and the whole model has significant explanatory power (important at the level of 0.001).

The most powerful independent variable is the quality of urban transport, measured in our model by the volume of transport work (translating into the frequency and density of the network). An increase in urban transport performance results in an increase in demand for this service. 
On the other hand, the results concerning the ticket price are surprising. The variable is not significant. This is a different result from the one obtained earlier in many analyses conducted in other countries (Matas, 2004; Deb and Filippini, 2015; Dargay and Hanly, 2002; Brechan, 2015; Daldoul et al., 2016). This suggests that in Polish conditions the ticket price is not very important for the passenger, probably since it does not exceed the threshold at which demand becomes sensitive to change (cf. Dargay and Hanly, 2002).

Another positive (though rather weak) impact on demand is the population density. In cities with a higher population density, there is a higher nuisance associated with increased traffic and in this case public transport can be a more advantageous alternative. Moreover, personal income is of weak significance. It is positively correlated with our dependent variable which means that the greater the welfare of the inhabitants, the higher the demand for public transport. It suggests that city public transport has stopped being considered an inferior good, although this relationship is very weak.

The population size requires a separate comment. We know from earlier discussion that size makes a difference in the demand for public transport; however, the relationship is not linear. But, due to very high collinearity with other independent variables, it was eventually excluded from our model, so its role is reflected in an indirect way only.

Table 3: Results of the Fixed Effects model ${ }^{\mathrm{a}}$ explaining demand for local public transport in 2014-2017

\begin{tabular}{lcc}
\hline \multicolumn{1}{c}{ Variable } & Coefficient & $\begin{array}{c}\text { Level of significance } \\
\text { of regression coefficient }\end{array}$ \\
\hline Ln (Vehicle-kilometers per capita) & 0.178 & 0.001 \\
Ln (Per capita personal income tax) & 0.0028 & 0.071 \\
Price & -0.035 & Non-significant \\
Density & 0.00001 & 0.028 \\
\hline
\end{tabular}

Note: ${ }^{\mathrm{a}} \mathrm{F}(4,85)=12.31 . \mathrm{R} 2=0,68$ (R2 within $\left.=0.133\right)$. Number of observations: 331. Number of groups: 86

Source: Own calculations

In addition, for those independent variables which turned out to be significant we have calculated coefficients of demand elasticity, which are based on single independent variable regression models, constructed for those variables which proved to be significant in our main multi-variable regression (see Table 4). The increase of frequency of bus operation stimulates the demand - one more vehicle-kilometer per capita results in 0.678 more journeys per year for the average resident of the city. The effect of population density is similar - an increase by one (person per square kilometer) translates into 0.008 additional journeys by the citizen. Finally, increased personal income generates additional journeys also, but in this case the relationship is very weak. 
Table 4: Coefficients of demand elasticity for city public transport in Poland

\begin{tabular}{lcc}
\hline & Demand elasticity coefficient & Significance of the model \\
\hline Vehicle-kilometers per capita & 0.678 & 0.0003 \\
Per capita personal income tax & 0.018 & 0.127 \\
Population density & 0.008 & 0.000 \\
\hline \multicolumn{3}{c}{ Source: Own calculations }
\end{tabular}

\section{Discussion and conclusions}

The study confirms that when estimating the parameters of the demand function for public transport services it is necessary to consider both the environment in which urban transport functions (to which our first hypothesis referred) and the factors related to the policy pursued by the city (to which the second hypothesis referred). This does not mean, however, that all the detailed hypotheses have been confirmed.

The most powerful independent variable - as in some previous studies conducted in other countries - is the density of the network of city public transport (measured in our study by the total transport work). Similar observations have appeared earlier in Polish literature in relation to railway connections - increasing the frequency of connections often turns out to be a recipe that helps to reverse the trend of falling passenger numbers (Król and Taczanowski, 2016; Trammer, 2019). As in several earlier studies, we treated this variable as an estimate of the quality of the service offered. The very strong impact of accessibility on demand growth may indicate the desired direction of local authority transport policy. As shown in section 4, the decline in demand most often appears as a problem in the group of medium-sized cities (between 60,000 and 100,000 inhabitants). Our results show that actions aimed at reducing the frequency of journeys or eliminating some connections may exacerbate the problems to a greater extent, and not constitute their remedy. They will not solve the problem of the decreasing number of passengers using public transport. This type of action although in the short term contributes to the reduction of the cost of the service - in the long term will cause the deepening of negative downward trends and will contribute to the eventual marginalization of the urban transport service. Indirectly, it will generate a spiral of problems related to the congestion of streets with passenger cars, increased noise and air pollution.

Interestingly, out of the two quality operational variables tested at the model building stage, only the availability measured by the amount of transport work turned out to be relevant. The existence of alternative (to buses) mean of public transport has not improved the prediction power of the model. Similarly, the variable expressing the rolling stock age structure (tested in our study to a limited extent only, due to problems with data availability) - similar to the Romilly study (2001) - turned out to be insignificant. This is an important result in Polish conditions, since public intervention in public transport often targets this factor. Only in 2018 did municipalities invest PLN 2.15 billion (about 500 million euro) in the purchase of rolling stock and 
the development of public transport networks, and in the last five years (2014-2018), a total of PLN 6.9 billion $^{2}$ (more than 1.5 billion euro). This, of course, does not mean that rolling stock renovation does not make sense, but indicates that this is not a major factor in attracting new passengers. Far from the decisive role of the rolling stock age in generating demand for public transport was also indicated in some earlier studies (Wolański et al., 2016).

As in the earlier Brechan (2017) study, it is quality, not price, that plays a more important role in generating the volume of traffic. The price of a single ride on local public transport in Poland is not very important for residents, nor is the introduction of various kinds of discounts and exemptions from fares. In any case, the impact of such measures cannot be quantified using the chosen statistical methods. Of course, the situation could change radically if budget subsidies for the operation of public transport were eliminated. The price would need to rise about three times its current rate and it would significantly exceed the price elasticity threshold, so the demand would start to fall rapidly, with all the negative consequences of such a trend. Public transport is a merit good and subsidizing its operation, which allows tariffs to be kept at an acceptable low level, remains an important element of transport policy.

The impact of the wealth of the population on demand is perhaps the most difficult to interpret. In our main model a higher level of personal income translates into a higher demand for city public transport, but the relationship is of very low statistical significance (close to the 0.1 threshold). And, depending on the exact model specification in some other variants, it turned out to be insignificant or - in some others - the sign was changing to negative (with a similarly low level of statistical significance). We believe that it reflects the 'transitional' character of the variable. Until recently in Poland, public transport used to be - similar to results of previous research (e.g. Dargay and Hanly, 2002; Bresson et al., 2003) - an inferior good. Along with the increase in wealth, preferences regarding the choice of means of transport were changing; wealthier people often decided to move by car. But in recent years the cultural shift related to increasing climate change and environmental consciousness, as well as increasing traffic jam problems and the increasing quality of public transport in many Polish cities, a change of attitude has come about. Using public transport has become increasingly popular (or even fashionable) among middle class citizens. Another illustration of the changing perception of private cars as a major means of city transport is provided by the extremely fast development of city bike rentals in several major Polish cities over the last few years. But the shift started relatively recently and has not been completed yet, so there are two competing views of public transport at the moment that coexist in local communities. This complex interpretation explains why the relationship is weak, and swings between negative and positive depending on the detailed model specifications.

2 Own calculations based on cities' reports on budget execution. 
The size of an urban center is also important - maintaining high demand is easier in the largest urban agglomerations. However, the impact of this variable is non-linear. It is important when we are talking about a group of the largest cities, roughly coinciding with regional capitals. 15 out of 18 regional capitals have over 150,000 inhabitants, and it is in this group that the changes consisting in the increase in demand are the most dynamic. However, when we are dealing with a city only slightly or much smaller than this size threshold, it is no longer of great statistical significance.

Contrary to the original assumptions, other features of the social and economic environment, such as the wealth of the city budget or unemployment levels, turned out to be irrelevant in relation to the demand for local public transport.

In conclusion, research on demand determinants is an important element of urban transport policy planning and our results confirm that city policies do matter in the generation of demand for local public transport. This study helps to fill a gap in the existing knowledge on the actual impact of various factors on the demand for public transport services in Polish cities and, at the same time, it opens the space for further research in this area. One potential improvement of our results might be provided by the collection of data, which is currently missing, but which may have a significant impact on the demand for public transport. The speed of city trams and buses is a good example of such missing information. In the future it would be also worth taking into consideration the impact of variables that are not directly related to the public transport offer, but to activities in its environment, such as road construction, parking policy or the development of bicycle paths and city bike systems. We do not think that this research would radically change the meaning of the conclusions of this article, but it could enrich and complement them.

Aknowledgement: This work was supported by National Science Centre (Narodowe Centrum Nauki) under grant no. 2015/19/B/HS4/02898 ('Fees for local public services - financial and political importance').

\section{References:}

1. Bąkowski, W., 'Metodyka badania wpływ segmentów rynku na popyt w miejskim transporcie zbiorowym - ujęcie modelowe' [Research Methodology on the Impact of Market Segmentation on the Demand on Urban Public Transport - A Model Approach], 2014, Transport Miejski i Regionalny, vol. 3, pp. 4-8.

2. Brechan, I., 'Effect of Price Reduction and Increased Service Frequency on Public Transport Travel', 2017, Journal of Public Transportation, vol. 20, no. 1, pp. 139-156.

3. Bresson, G., Dargay, J., Madre, J. and Pirotte, A., 'The Main Determinants of the Demand for Public Transport: A Comparative Analysis of England and France Using Shrinkage Estimators', 2003, Transportation Research Part A: Policy and Practice, vol. 37, no. 7, pp. 605-627.

4. Daldoul, M., Jarboui, S. and Dakhlaoui, A., 'Public Transport Demand: Dynamic Panel Model Analysis', 2016, Transportation, vol. 43, no. 3, pp. 491-505. 
5. Dargay, J.M. and Hanly, M., 'The Demand for Local Bus Services in England', 2002, fournal of Transport Economics and Policy, vol. 36, no. 1, pp. 73-91.

6. Deb, K. and Filippini, M., 'Public Bus Transport Demand Elasticities in India', 2013, fournal of Transport Economics and Policy, vol. 47, no. 3, pp. 419-436.

7. Dydkowski, G., Tomanek, R. and Urbanek A., 'Taryfy i systemy poboru opłat w miejskim transporcie zbiorowym' [Tariffs and Toll Collection Systems in Municipal Public Transport], Wydawnictwo Uniwersytetu Ekonomicznego w Katowicach, Katowice, 2018.

8. Hebel, K., 'Zmiany preferencji i zachowań transportowych mieszkańców Gdyni w latach 1996-2013' [Changes in Preferences and Transport Behavior of Gdynia Residents in 19962013], 2014, Transport Miejski i Regionalny, vol. 4, pp. 10-14.

9. Hebel, K. and Horoń, M., 'Popyt na usługi komunikacji miejskiej' [Demand for Public Transport Services], in Wyszomirski, O. (ed.), Gospodarowanie w komunikacji miejskiej [Public Transport Management], Gdańsk: Wydawnictwo Uniwersytetu Gdańskiego, 2002, pp. 57-72.

10. Holmgren, J., 'Meta-analysis of Public Transport Demand', 2007, Transportation Research Part A: Policy and Practice, vol. 41, no. 10, pp. 1021-1035.

11. Holmgren, J., 'An Analysis of the Determinants of Local Public Transport Demand Focusing the Effects of Income Changes', 2013, European Transport Research Review, vol. 5, pp. 101-107.

12. Król, M. and Taczanowski, J., 'Regionalne przewozy kolejowe w Polsce, Czechach i na Słowacji' [Regional Rail Transport in Poland, the Czech Republic and Slovakia], Oficyna Wydawnicza SGH, Warszawa, 2016.

13. Matas, A., 'Demand and Revenue Implications of an Integrated Public Transport Policy: The Case of Madrid', 2004, Transport Reviews, vol. 24, no. 2, pp. 195-217.

14. Menes, M., 'Ewolucja zbiorowego transportu publicznego w polskich miastach w latach 1990-2013' [Evolution of Collective Public Transport in Polish Cities in the Years 19902013], 2016, Transport Samochodowy, vol. 2, pp. 23-34.

15. De Palma, A. and Lindsey, R., 'Optimal Timetables for Public Transportation', 2001, Transportation Research Part B, vol. 35, no. 8, pp. 789-813.

16. Poliak, M., Poliakova, A., Mrnikova, M., Simurkova, P., Jaskiewicz, M. and Jurecki, R., 'The Competitiveness of Public Transport', 2017, Journal of Competitiveness, vol. 9, no. 3, pp. 81-97.

17. Romilly, P., 'Subsidy and Local Bus Service Deregulation in Britain', 2001, fournal of Transport Economics and Policy, vol. 35, no. 2, pp. 161-193.

18. Trammer, K., 'Ostre cięcie' [A Sharp Cut], Wydawnictwo Krytyki Politycznej, Warszawa, 2019.

19. Wolański, M., Karolak, A., Pieróg, M., Mazur, B. and Mikiel, P., 'Raport o stanie komunikacji miejskiej w Polsce w latach 2009-2015' [Report on the Condition of Public Transport in Poland in 2009-2015], Izba Gospodarcza Komunikacji miejskiej, Warszawa, 2016. 